\title{
Research on the Path of Transformation and Upgrading of High-star Hotel in the Internet Era
}

\author{
Ying Liu ${ }^{1, a}$ and Chunyan Wang ${ }^{1, b, ~ * ~}$ \\ ${ }^{1}$ College of Business Administration, Jilin Engineering Normal University, Changchun, China \\ a993299035@qq.com, b541012329@qq.com \\ * The corresponding author
}

\begin{abstract}
Keywords: High-Star hotel; Enterprise's transformation and upgrading; Strategy; China; Internet Era
\end{abstract}

\begin{abstract}
With the rapid development of the Internet in China, it has an important impact on the social and economic fields. Driven by the dual requirements of demand and Internet technology, the transformation and upgrading of China's hotel enterprises are facing pressure from external and internal. China's high-star hotels can be achieved their own transformation and upgrading through the transformation and upgrading of the capacity system, innovation driven, demand driven and government driven.
\end{abstract}

\section{Introduction}

According to the statistics from China Internet Network Information Center (CNNIC), as of December 2016, China's Internet users reached 713 million, Internet penetration rate of 53.2\% [1]. The Internet has penetrated into all fields of society and economy. Report on the work of the Chinese government in 2015 proposed the plan of action of the "Internet plus", which means the combination the Internet with the enterprise becomes a mainstream trend of the transformation and upgrading of enterprises [2]. The enterprise through modern information technology, the integration of Internet and traditional industries, optimize the Internet in the allocation of social resources and integration, to subvert and reconstruct the traditional industry, to achieve the transformation and upgrading, cross-border development, create more new industries and new industry, promote innovation and productivity, faster and more flexible the way to meet the diverse needs of consumers, thereby forming a new form of economic development.

According to the Statistical Bulletin of National Star announced by Hotel National Tourism Administration, from 2006 to2015 the number of five-star hotels in China increased from 302 up to 789, the number of rooms from 115200 rooms (or suites) increased to 269100 rooms (or suites) [3], can been seen in Fig. 1 and Fig. 2. In ten years, the number of star hotels increased by 1.61 times, the number of rooms increased by a factor of 1.34, the number of China's five-star hotels in the past ten years can be said to be blowout growth.

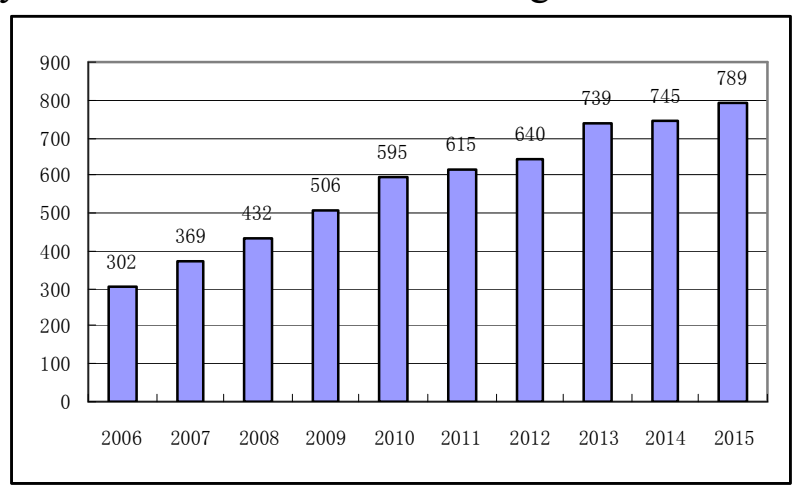

Figure 1. The number of China's five-star hotels from 2006 to 2015

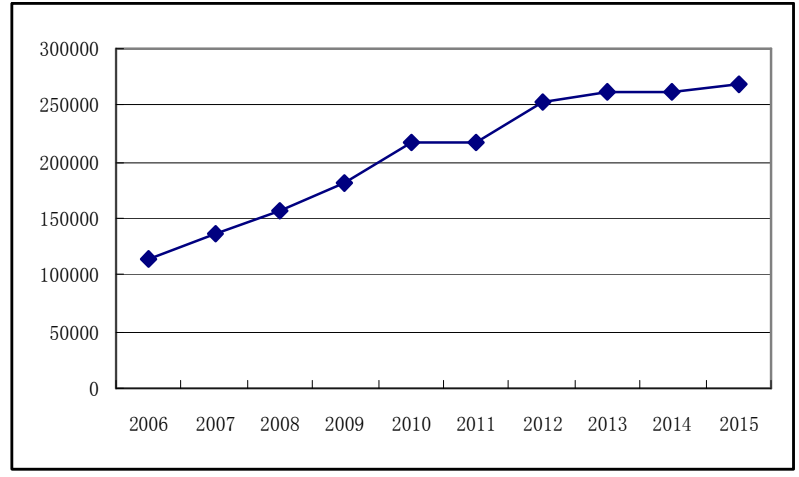

Figure 2. The number of rooms in China's five-star hotel from 2006 to 2015 
However, in recent years, by the impact of the national macroeconomic regulation \& control and the financial crisis, China's five-star hotels has in a dilemma, especially in terms of revenue and profit, a downward trend (shown in Fig. 3) [3]. With the Chinese decline in economic growth has entered a new normal, domestic enterprises are facing many difficulties and challenges, "Internet plus" era, all walks of life also actively adjust and carry out the transformation and upgrading [4]. The competition in the hotel industry is also facing an unprecedented situation, especially the majority of five-star hotels in a negative state of earnings. How to realize the transformation and upgrading of enterprises in Internet Era has become the most urgent problem. The hotels also should represent this general trend, which relates to the sustainable development of enterprises and the hotel industry hotel.

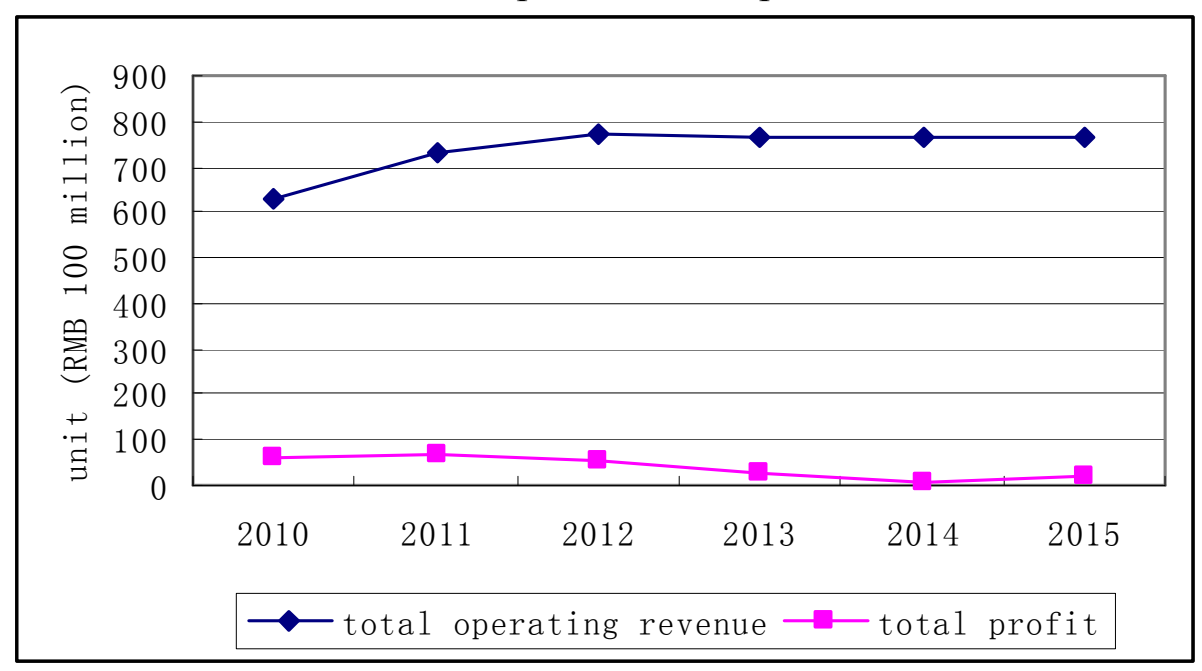

Figure 3. The total revenue and total profit of five-star hotels in China form 2010 to 2015

\section{Concept of the Transformation and Upgrading of Hotels}

In the term of studying the transformation and upgrading of enterprises, the researches by foreign scholars mainly focused on strategy, influencing factors and transition path model, etc.. In the aspects of the upgrading of enterprises, the researches are mainly concentrated in the definition, influencing factors, upgrading path and so on. Through the study of foreign literature, we find that the foreign research is rarely concerned about how to transform the enterprises in developing countries. The content and framework of the research has not yet formed a system, corresponding to the actual situation in China, it should be more in line with the reality of China's research perspective. Different strategies and measures are proposed for heterogeneous enterprises. The domestic research mainly focuses on the type and modes of enterprise transformation and upgrading, the path of transformation and upgrading, and the factors affecting the transformation and upgrading.

Upgrade (Transformation \& Upgrading) has always been a hot issue in theory and practice, and refers to the process of the evolution of enterprises from the low level of technology and the state of low added values through the transformation of organizational restructuring, management change and development model [5]. Transformation and upgrading of the hotel business can be understood from several aspects: hotel companies in the field of industry transformation and upgrading, or in different industries or different areas of [6-8]. Transformation and upgrading of the level of organization and management of the hotel business, there is the hotel enterprises through access to technology, market and other aspects of improvement, to improve their position in the production or industry, enhance product added value.

The upgrade includes not only the hotel enterprise level service, product adjustment and transformation of hotel enterprises, including hotel enterprises in an all-round and comprehensive transformation, including the business model, the re allocation of capital, human resources and other factors of production and trading right. 


\section{Dynamic Model of the Transformation and Upgrading of High-star Hotels in China}

The necessity of enterprise transformation and upgrading can come from two aspects: external factors and internal factors [9-11]. Transformation and upgrading is the behavior of the enterprise, not only by the internal behavior of enterprises, but also by the external environment. From the dynamic model of the transformation and upgrading of hotel enterprise perspective, the change of external environment leads to the emergence of new external factors, so as to upgrade brings power and opportunities, but also to upgrade brings opportunities and challenges. Similarly, changes in the internal environment has led to a new state of internal factors, which also bring the transformation and upgrading of power and pressure. Different factors, different states on the transformation and upgrading of the opportunities and power caused by the different sizes, these opportunities and power interaction, and ultimately the formation of the transformation and upgrading of the hotel business power (Fig. 4).

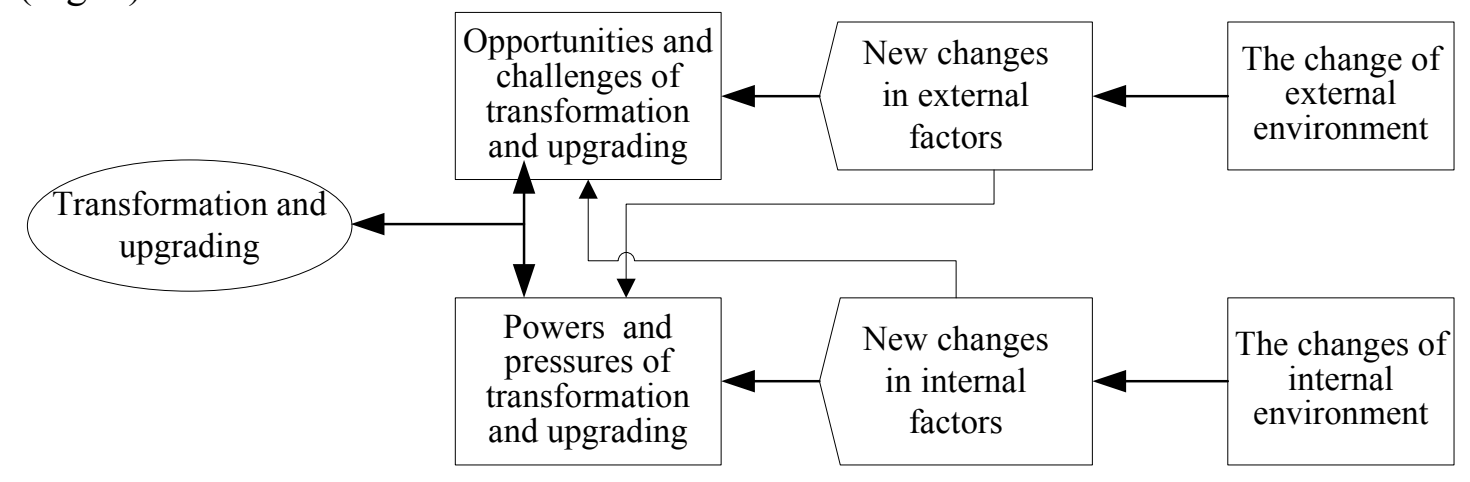

Figure 4. The dynamics model of transformation and upgrading for China's hotels

\section{The Transformation and Upgrading Strategies of China's High-star Hotel in the Internet Era}

Foster the Ability of Transformation and Upgrading of High-star Hotel. The ability of the transformation and upgrading of the hotel business is the construction of [12-13] under the interaction of a number of subdivision capabilities, including the integration of human, financial, material, technology, information and other resources. Environmental response ability mainly includes the market capability and resource integration capability and enterprise network relationship capability; economic benefit is the core and goal of the transformation and upgrading of hotel enterprises; the innovation ability is the key to the transformation and upgrading of enterprises; brand quality is an important guarantee for the transformation and upgrading of hotel enterprises; structure optimization is to support the transformation and upgrading power of the hotel business intelligence; is the level of technical support for the transformation and upgrading of enterprises. Therefore, the transformation and upgrading of the hotel business can also be evaluated and improved from these aspects.

Rely on Innovation to Promote the Transformation and Upgrading of China's High-star Hotels. The establishment of innovative R \& D centers, universities, and research institutions to establish a joint research and development institutions and personnel training mechanism, strengthen the cultivation of entrepreneurs, to create the environment to attract talents and enhance the capability of independent innovation of hotel enterprises, promote the transformation and application of scientific research achievements. Rely on the product innovation to promote enterprise innovation, and gradually expand the original innovation of the hotel business process, speed and scale, a strong impetus to the hotel business from manufacturing to create transformation.

From the overall strategies of the hotel, the operational aspects of all aspects of optimization and improvement, and through the Internet technology to improve the efficiency of production, enhance the customer experience under the line. The hardware and software to create the high quality service, and realize the intelligent terminal, upgrading of hotel experience, this is the hotel industry once again change in the Internet era, the focus of future work is also a core competitive advantage. 
In the Internet era, the hotel enterprises need to build their own marketing platform, establish the membership management mechanisms and systems, grasp the members and the group of large customer resources, and cultivate loyal customers. According to the traditional line service providers to use OTA platform or APP tools such as mobile Internet technology, to create the Internet marketing team, direct booking, the establishment of direct sales system of hotel oneself, develop and strengthen membership management. For purely online service platform, we must pay attention to the next line of service experience. Online service platform is the core of the consumer experience offline.

Drive the Transformation and Upgrading of China's High-star Hotel by Demand. The upgrading of the demand guides the optimization of industrial chain division of labor. Changes in income levels and the increase of consumer groups demand driven consumption level, so as to provide new demand power transformation and upgrading of hotel enterprises, promote the hotel enterprise input structure changes, promote technological progress of enterprises, creating new demand, promote the hotel enterprises more professional, quality, characteristics and new development, to production service industry transformation and extension. From the hotel on the downstream isolation and development of science and technology development, financial services, logistics, trade, marketing, information consulting, public services and other professional services companies in a variety of ways, promote the agglomeration of hotel enterprises to extend the production service industry, to better promote the coordination and interaction between hotel service industry and other industries.

Promote the Transformation and Upgrading of China's High-star Hotel by Government. Relevant government departments should pay close attention to management status and development trend of high star hotel enterprises, from the actual operating situation and the trend of continuously improve the service management system of industry, improve the service management level. It can be divided into three aspects: one is to increase support for the high star hotel enterprise upgrade policy transformation; the two is to strengthen the industry monitoring and management; three is promoted to upgrade the support and protection of the service ability of hotel enterprise transformation. Not only to improve the overall service quality and level of the hotel industry, but also for the transformation and upgrading of the hotel business escort.

The state should adopt tax incentives, risk compensation and reward policy, strengthen enterprise planning, combined with insist on supporting the superior and eliminating the inferior, upgrading and elimination of backward integration, mergers and reorganization combined with the closure and bankruptcy of the hotel guide and encourage the innovation and development of enterprises, to further optimize the structure of enterprise, promote the transformation and upgrading of hotel enterprises.

\section{References}

[1] Information on http://www.cnnic.net.cn/

[2] Q.P. Jiang: Frontiers, Vol. 4 (2015) No.10, p.52-63.

[3] Information on http://www.cnta.gov.cn/

[4] C.X. Huang and D. Wang: News and Writing, Vol. 32 (2015) No.5, p.5-9.

[5] J.S. Gans and S. Stern: Research Policy, Vol. 32 (2003) No.2, p.333-350.

[6] C.W. Zhao and Z.Y. Xu: Management World, Vol. 29 (2013) No.4, p.8-15+58.

[7] J. Humphrey and H. Schmitz: Governance and Upgrading: Linking Industrial Cluster and Global Value Chain Research (Trans Institute of Development Studies, Brighton 2000).

[8] H.Y. Li, J.X. Wu and J.W. Li: Management World, Vol. 27 (2011) No.9, p.1-6+73.

[9] N. Forbes and D. Wield: From Followers to Leaders: Managing Technology and Innovation in Newly Industrializing Countries (Trans Psychology Press, UK 2002).

[10] I. Herbert: Journal of Human Resource Costing \& Accounting, Vol. 13 (2009) No.3, p.221-244.

[11] J. Humphrey and H. Schmitz: Regional Studies, Vol. 36 (2002) No.9, p.1017-1027.

[12]H.G. He and Y.J. Zhang: Enterprise Economy, Vol. 33 (2013) No.5, p.13-17.

[13] S.S. Chen and Y. Li: Science \& Technology Progress and Policy, Vol. 32 (2014) No.4, p.80-83. 